\title{
Kajian Hukum Agraria terhadap Ketentuan Larangan Pengalian Hak Milik atas Tanah Gereja (Studi Kantor Sinode Gereja Masehi Injili di Halmahera)
}

\author{
Reli Jevon Laike \\ Fakultas Hukum Universitas Hein Namotemo \\ Jln. Kawasan Pemerintahan Kabupaten Halmahera Utara, Villa Bak I, Desa Gamsungi \\ Correspondence email: rely.laike@gmail.com
}

\begin{abstract}
Abstrak. Tujuan penelitian ini adalah mengkaji ketentuan Gereja Masehi Injili di Halmahera tentang larangan pengalihan hak milik atas tanah bagi pegaiorganik yang menyebutkan, setiap pegawai organik atau pensiunan yang mendapat penyerahan hak atas tanah yang telah berstatus status hak milik, dilarang mengalihkan, mengadaikan, atau perbuatan hukum lain. Di sisi lain ketentuan hak milik atas tanah menurut hukum agraria nasional, mempunyai wewenang yang luas artinya dapat mengalihkan, mengadaikan atau sepanjang tidak bertentangan dengan hukum yang berlaku. Selain itu Penelitian ini bertujuan mengkaji konsep pengaturan gereja tentang larangan pengalihan hak milik atas tanah dan dihubungkan dengan konsep hukum agraria nasional. Penelitian ini penelitian hukum normatif. Hasil penelitian ditemukan pertama, ketentuan hak milik atas tanah yang diatur dalam ketentuan Gereja dalam pelaksanaannya terdapat pertentangan dan perbedaan mendasar dengan konsep yang diatur dalam hukum agraria nasional. Kedua pemegang hak atas tanah yang telah mendapat penyerahan hak atas tanah dari gereja tidak mendapat jaminan kepastian hukum dengan adanya ketentuan gereja yang mengatur larangan pengalihan hak milik atas tanah.
\end{abstract}

Kata Kunci: Gereja; Ketentuan; Hak Atas Tanah

\begin{abstract}
The provisions of the evangelical Christian Church in Halmahera on the prohibition of transferring property rights on the land mention, any organic or retired employee who is entitled to the submission of land rights which has status of property, shall not divert, adjudicate, or other legal action. While the provisions of the land rights under the National Agrarian Law, having broad authority means that it can divert, adjuct or as long as not contrary to applicable law. This study aims to examine the concept of church arrangement on the prohibition of transferring property rights on land and associated with the concept of national agrarian law. Research is normative legal research. The results of the research were found first, the provisions of the property of land governed by the provisions of the Church in the implementation there are conflicts and fundamental differences with the concepts governed in national agrarian law. The two rights holders of the land who have received the surrender of land from the church do not have a guarantee of legal certainty with the provisions of the Church governing the prohibition of the transfer of property rights to the land.
\end{abstract}

Keywords: church; conditions; land rights

\section{PENDAHULUAN}

Dengan diundangkannya Undang-Undang Nomor 5 Tahun 1960 Tentang Peraturan Dasar Pokok-Pokok Agraria (selanjutnya disingkat UUPA) demikianlah Indonesia untuk pertama kalinya mempunyai dasar perundang-undangan untuk menyusun lebih lanjut hukum agraria nasionalnya sebagai perwujudan dari Pancasila, berlandaskan UndangUndang Dasar 1945. Pengundangan UUPA tersebut tidak terlepas dari sejarah dan analisis normatif hukum agraria pada zaman Hindia Belanda dengan asas domein verkelaring yang menyertainya, sangat bertentangan dengan hukum dan rasa keadilan masyarakat ${ }^{1}$. UUPA merupakan salah satu sumber hukum formal dalam membahas dan memahami hak milik atas tanah. Namun sebelum memasuki intik pokok pembahasan, untuk mempersandingkan dan mengatar pemahaman tentang hak milik atas tanah, perluh kiranya penulis uraikan sedikit tentang konsep hak atas tanah menurut UUPA.

UUPA sebagai perwujudan dari Pancasila, berlandaskan Undang-Undang Dasar Negara Republik Indonesia Tahun 1945 ( selanjutnya di singkat UUD NRI tahun 1945) ${ }^{2}$. UUPA berpangkal pada pendirian apa yang ditentukan dalam pasal 33 ayat (3) UUD NRI tahun 1945 tidak perlu dan tidaklah pula pada tempatnya, bahwa bangsa Indonesia ataupun Negara bertindak sebagai pemilik tanah. Norma tersebut untuk menegaskan pada mencabut dan menghilangkan sifat-sifat hukum peninggalan Belanda yang dianggap bertentangan dengan jiwa bangsa Indonesia. Dari sudut inilah harus dilihat arti ketentuan dalam pasal 2 ayat (1) UUPA yang menyatakan, bahwa "Bumi, air dan ruang angkasa, termasuk kekayaan alam yang terkandung di dalamnya, pada tingkatan yang tertinggi dikuasai oleh Negara". Sesuai dengan pangkal pendirian tersebut di atas perkataan "dikuasai" dalam pasal ini bukanlah berarti

${ }^{1}$ Moh. Mahfud, 2011. Politik Hukum Di Indonesia, PT Raja Grafindo Persada,Jakarta hlm 56.

${ }^{2}$ Boedi Harsono, 2008. Hukum Agararia Indonesia (sejarah pembentukan Undang-Undang Pokok Agraria dan Peraturan Pelaksana). PT Djambatan, Jakarta hlm 42. 
"dimiliki”, akan tetapi adalah pengertian, yang memberi wewenang kepada Negara, sebagai organisasi kekuasaan dari Bangsa Indonesia itu, untuk pada tingkatan yang tertinggi dikuasai oleh negara. Termasuk dalam ketentua tersebut mencakup pula hak milik atas tanah yang di atur dalam UUPA tersebut

UUPA merupakan salah satu sumber hukum formal dalam membahas dan memahami hak milik atas tanah. UUPA telah mencantumkan dasar-dasar pengaturan, penguasaan, pemilikan, penggunaan, peralihan dan pemanfaatan, dengan tujuan untuk mengurangi ketimpangan dalam kepemilikan $\tan ^{3}{ }^{3}$ dan menjamin kepastian dan perlindungan hukum hak milik atas tanah. Mengenai hak milik atas tanah diatur dalam Pasal 20 hingga Pasal 27 UUPA $^{4}$. Dalam ketentuan tersebut menetapkan bahwa hak milik adalah hak yang "terkuat dan terpenuh" yang dapat dipunyai orang atas tanah. Kata-kata "terkuat dan terpenuh" bermaksud membedahkannya dengan hak-hak lainnya, untuk menunjukkan, bahwa di antara hak-hak atas tanah yang dapat dipunyai orang hak miliklah yang "ter" kuat dan terpenuh. Terkuat dan terpenuh artinya tidak adanya batas waktu penguasaan tanah dan luas lingkup penggunaannya, yang meliputi baik untuk diusahakan ataupun digunakan sebagai tempat membangun sesuatu ${ }^{5}$.

Konsep hak milik sebagaimana yang terdapat dalam UUPA merupakan norma dasar dalam pelaksanaan maupun pembentukan hukum yang ada di bawahnya. Hal ini sebagai wujud unifikasi hukum yang dapat memberikan perlindungan dan kepastian hukum bagi pemegang hak atas tanah. Melalikan hal tersebut akan berakibat pada ketidak pastian hukum dalam pengaturannya, dengan sendirinya menimbulkan ketidak harmonisasi hukum dan peraturan yang diberlakukan. Hal inilah yang terjadi pada badan hukum keagamaan Gereja Masehi Injili Di Halmahera (selanjutnya disingkat GMIH). Dimana sebuah ketentuan GMIH, yang mengatur khusus tentang pembatasan pengalihan hak milik atas tanah yang sudah dialihkan/diserahkan oleh GMIH ke pegawai organik. Pegawai organik yang mempunyai hak milik atas tanah yang diserahkan oleh GMIH, wewenangnya hanya terbatas pada menggunakan tanahnya untuk mendirikan bangunan khususnya rumah tempat tinggal. Hal tersebut sebagaimana tertdapat dalam Peraturan GMIH Tahun 2003 tentang Khusus Pembagian Tanah Perkebunan GMIH Bagi Pegawai Organik/Pensiunan Untuk Lokasi Perumhan di Wari dan Wosia. Lebih jelasnya ketentuan tersebut menetapkan status hak milik atas tanah yang telah dimiliki pegawai organik melalui penyerahan oleh GMIH dibatasi wewenangnya. Pembatasana wewenang adalah tanah hak milik pribadi yang riwayatnya berasal dari GMIH tidak bisa dialihkan (jual) ke pihak lain, tidak bisa dijadikan jaminan utang, baik di bank, maupun jasa keuangan lainnya.

Ketentuan GMIH tersebut menimbulkan ketidak pastian hukum baik dari segi norma maupun dalam pelaksanaan hukum konkret. Pengaturan tersebut haruslah mencermikan kepastian hukum yang tetap bersandar pada konsep dan asas hukum yang ada. Salah satunya adalah, untuk memberikan kepastian hukum dalam penerapan hukum konkret, maka asas hukum merupakan pikiran dasar yang bersifat umum dan mendasari atau yang terdapat di dalam atau di belakang peraturan hukum konkret ${ }^{6}$. Dengan kata lain, asas hukum yang tersirat di dalam peraturan hukum konkret misalnya asas itikat baik, semua hak atas tanah mempunyai sosial dan lainnya, selalu mencerminkan dalam penerapan peraturan. Dalam UUPA terkuat dan terpenuh merupakan asas yang terkandung dalam hak milik atas tanah. Asas ini berkaitan langsung pada status penguasaan hak milik atas tanah dan hak-hak atas tanah lainnya. Penegasan hak milik menurut Pasal 20 dan Pasal 25 UUPA dapat beralih dan dialihkan, dapat dijadikan objek hak tanggungan, dan hak milik itu bisa diikat hak pakai atau hak guna bangunan di atas tanah milik, pemilik tanah mempergunakan atau mengambil manfaat dari tanah yang dihaki ${ }^{7}$. Pengecualian dari pemberian hak atas tanah menurut UUPA, misalnya pemberian hak guna usaha kepada subjek hukum hanya terbatas untuk keperluan pertanian perikanan, peternakan, atau perkebunan ${ }^{8}$.

Berdasarkan pada pelaksanaannya, pegawai organik yang memperoleh hak milik dari tanah GMIH tidak mendapat kepastian dan perlindungan hukum sebagaimana yang dimaksudkan dalam ketentuan GMIH. Sehingga hal ini menyisakan permasalahan implementasi dari penggunaan hak milik atas tanah oleh pegawai organi GMIH. Berkaitan dengan hal tersebut, sehingga menarik oleh penulis untuk mengkaji guna mendapat pemikiran yang rasional berdasarkan asas yang terkadung dalam Pancasila, Undang-Undang Dasar Negara Republik Indonesia Tahun 1945 dan UUPA.

Berdasarkan fakta dan latar belakang masalah yang telah diuraikan tersebut di atas, maka permasalahan yang dikaji adalah, pertama bagaimanakah konsep ketentuan larangan pengalihan hak milik atas tanah gereja dan

\footnotetext{
${ }^{3}$ Budi Sastra Panjaitan, 2020. "Pembentukan Pengadilan Pertanahan Sebagai Solusi Penyelesian Sengketa Pertanahan", Jurnal Bina Hukum Lingkungan, 4 (1), 2020: 269.

${ }^{4}$ Undang-Undang Nomor 5 Tahun 1960 Tentang Pokok-Pokok Agraria, 2008, PT Pradnya Paramita, Jakarta.

${ }^{5}$ Ibid Boedi Harsono, 2008, 48.

${ }^{6}$ Sudikmo Mertokusumo, 2012. Teori Hukum, PT Cahaya Atma Pustaka, Yogyakarta, hlm 46.

${ }^{7}$ Urip Santoso, 2014. Pendaftaran Dan Peralihan Hak Atas Tanah, PT Kencana, Jakarta, hlm 76.

${ }^{8}$ Urip Santoso. 2017. Hak Atas Tanah, Hak Pengelolaan, \& Hak Milik Atas Satuan Rumah Susun, PT Kencana, Cimanggis, 61.
} 
hubungannya dengan hukum agraria ?, kedua apakah ketentuan larangan pengalihan hak milik atas tanah gereja memberikan kepastian hukum bagi pemegang hak ?

\section{METODE}

Adapun metode yang digunakan dalam penelitian ini adalah penelitian hukum normatif dengan cara melakukan studi pustaka yaitu dengan titik fokusnya terkait ketentuan GMIH tentang larangan pemindahan hak milik atas tanah yang bagi pegawai organik. Selanjutnya studi pustaka ini terkait dengan doktrin, pendapat para ahli dan peraturan terkait hak milik atas tanah. Pendekatan yang digunakan dalam penelitian ini adalah pendekatan undang-undang, dengan menitik beratkan pada UUPA.

Selanjutnya teknik pengumpulan data ialah dengan cara studi pustaka terkait langsung dengan ketentuan GMIH, wawancara dilakukan sebagai data tambahan. Untuk menganalisis data sebagaimana hasil yang diperoleh, tekniknya ialah dengan menganlisis data primer sebagai bahan utama dan data sekunder. Data primer dalam hal ini bahan hukum primer, seperti UUD NRI Tahun 1945, UUPA dan peraturan GMIH. Bahan hukum sekunder dalam hal ini buku-buku dan hasil-hasil penelitian berupa jurnal yang terkait langsung dengan penulisan ini. Bahan tersier dalam hal ini kamus hukum. Semua data tersebut dijadikan rujukan untuk mendapat suatu kesimpulan dengan tujuan untuk bagaimana menemukan aspek hukum dalam ketentuan GMIH dan ketentuan hukum dalam UUPA.

\section{HASIL DAN PEMBAHASAN \\ Ketentuan Larangan Pengalihan Hak Milik Atas Tanah Gereja Dan Hubungannya Dengan Hukum Agraria}

Tanah dalam pengertian yuridis ialah hak-hak penguasaan atas tanah. Penguasaan dalam arti yuridis adalah penguasaan yang dilandasi hak, yang dilindungi oleh hukum pada umumnya memberi wewenang kepada pemegang hak untuk menguasai secara fisik tanah yang dihaki, misalnya pemilik tanah mempergunakan atau mengambil manfaat dari tanah yang dihaki, tidak diserahkan kepada pihak lain ${ }^{9}$. Menurut Sudikno Mertokusumo, hak adalah kepentingan yang dilindungi oleh hukum sedangkan kepentingan adalah tuntutang perorangan atau kelompok yang diharapkan dipenuhi ${ }^{10}$. Isi hak penguasaan ialah: kewajiban-kewajiban, wewenag-wewenang tertentu, dan larangan-larangan tertentu. Menurut pendapat Urip Santoso bahwa hak atas tanah adalah hak yang memberi wewenang kepada pemegang haknya untuk menggunakan dan/atau mengambil manfaat dari tanah yang dihakinya ${ }^{11}$. Berbicara hak atas tanah menurut hukum tanah nasional berdasarkan pada Pasal 5 UUPA bahwa " hukum agraria yang berlaku atas bumi, air dan ruang angkasa ialah hukum adat, sepanjang tidak bertentangan dengan kepentingan nasional dan negara, yang berdasarkan atas persatuan bangsa, dengan sosialisme Indonesia serta dengan peraturan-peraturan yang tercantum dalam Undang-undang ini dan dengan peraturan perundangan lainnya, segala sesuatu dengan mengindahkan unsurunsur yang bersandar pada hukum agama ${ }^{12}$.

Penegasan selanjutnya dalam Pasal 4 ayat (2) UUPA menetapkan bahwa "Hak-hak atas tanah yang dimaksud dalam ayat 1 pasal ini memberi wewenang untuk menggunakan tanah yang bersangkutan, demikian pula tubuh bumi dan air serta ruang yang ada di atasnya sekedar diperlukan untuk kepentingan yang langsung berhubungan dengan penggunaan tanah itu dalam batas-batas menurut undang-undang ini dan peraturan hukum lain yang lebih tinggi”. Wewenang hak atas tanah yang dipunyai oleh pemegang hak atas tanahnya, menurut Soedikno Mertokusumo sebagaimana dikutip oleh Urip Santoso ${ }^{13}$ dapat dibagi menjadi dua yaitu:

1. Wewenang Umum

Wewenang yang bersifat umum, yaitu pemegang hak atas tanah mempunyai wewenang untuk menggunakan tanahnya, termasuk juga tubuh bumi, air, dan ruang yang ada di atasnya sekedar diperlukan untuk kepentingan yang langsung berhubungan dengan penggunaan tanah itu dalam batas-batas menurut UUPA dan perturan yang lebih tinggi.

2. Wewenang Khusus

Wewenang yang bersifat khusus, yaitu pemegang hak atas tanah mempunyai wewenang untuk menggunakan tanahnya sesuai dengan macam hak atas tanahnya, misalnya wewenang pada tanah hak milik adalah dapat untuk kepentingan pertanian dan/untuk mendirikan bangunan, wewenang pada tanah hak guna bangunan adalah menggunakan tanah hanya untuk mendirikan dan mempunyai bangunan atas tanah yang bukan miliknya,

\footnotetext{
${ }^{9}$ Ibid Urip Santoso, 2014, hlm 23.

${ }^{10}$ Sudikno Mertokusumo, 2012. Mengenal Hukum Suatu Pengantar, PT Liberty, Yogyakarta, hlm 18.

${ }^{11}$ Urip Santoso, 2012. Hukum Agraria Kajian Komprehensif, PT Kencana, Jakarta hlm 24.
}

12 Muhammad Jefrry Maulidi, Analisis Hukum Tentang Peralihan Hak Milik Atas Tanah Dengan Bukti Akta Di Bawah Tangan Sebagai Dasar Pendaftaran Tanah Untuk Pertama Kali (Studi Di Kabupaten Lombok Tengah), Jurnal Kajian Hukum Dan Keadilan, Vol V, No. 3, hlm 419.

${ }^{13}$ Ibid Urip Santoso, 2014. HIm 43. 
wewenang pada hak guna usaha adalah menggunakan hanya untuk kepentingan usaha di bidang pertanian, perikanan, peternakan, dan perkebunan.

Dalam hukum tanah, tanah diartikan dalam arti yuridis, sebagai suatu pengertian yang telah diberikan batasan resmi oleh Undang-Undang Nomor 5 Tahun 1960 tentang Pokok-Pokok Agraria (UUPA) ${ }^{14}$. Hal tersebut ditegaskan dalam Pasal 4 UUPA, yang pada intinya bahwa, atas dasar hak menguasai dari negara, ditentukan adanya macammacam hak atas permukaan bumi, yang sibebut tanah, yang dapat diberikan kepada dan dipunyai orang-orang. Dengan demikian jelaslah bahwa tanah dalam pengertian yuridis adalah permukaan bumi. Tanah diberikan kepada dan dipunyai oleh orang dengan hak-hak yang disediakan oleh UUPA, adalah untuk digunakan atau dimanfaatkan. Pemberian tanah dengan hak-hak tertentu tidak akan bermakna jika penggunaannya terbatas hanya pada tanah sebagai permukaan bumi saja. Untuk keperluan apapun tidak bisa tidak, pasti diperlukan juga penggunaan sebagian tubuh bumi yang ada di bawahnya dan air serta ruang yang ada di atasnya. Hal tersebut telah ditegaskan dalam pada Pasal 4 ayat (2) yang menyatakan, hak-hak atas tanah bukan hanya memberi wewenang untuk mempergunakan sebagian tertentu permukaan bumi yang bersangkutan, yang disebut tanah, tetapi juga tubuh bumi yang ada di bawahnya dan air serta ruang yang ada di atasnya. Dengan demikian maka yang dipunyai dengan hak atas tanah itu adalah tanh, dalam arti sebagian tertentu dari permukaan bumi.

Boedi Harsono menyatakan bahwa dalam tiap hukum tanah terdapat pengaturan mengenai hak penguasaan atas tanah. Semua hak penguasaan atas tanah berisi serangkaian wewenang, kewajiban, dan/atau larangan bagi pemegang haknya untuk berbuat sesuatu mengenai tanah yang dihaki. Sesuatu yang boleh, wajib atau dilarang untuk diperbuat, yang merupakan isi hak penguasaan itulah yang menjadi kriteria atau tolak pembeda di antara hak-hak penguasaan atas tanah dalam hukum tanah ${ }^{15}$. Secara yuridis berbuat sesuatu yang dimaksud tersebut dapat berisi kewenangan privat, publik atau bahkan dapat sekaligus kewenangan publik dan privat. Tegasnya, pengertian penguasaan yang dimaksudkan dalam hak penguasaan atas tanah berisi kewenangan yang luas, tidak sekedar berisi kewenangan hak untuk menggunakan dan atau menjadikan tanah sebagai jaminan yang merupakan kewenangan perdata. Dalam pada itu, hak penguasaan atas tanah lebih luas daripada hak atas tanah. Untuk lebih mengefektifkan studi hukum agraria/tanah, Boedi Harsono yang pertama kali menyatakan bahwa ketika mempelajari hukum agraria/tanah perluh dilakukan dengan pendekatan pengertian hak penguasaan atas tanah sebagai lembaga hukum dan sebagai hubungan hukum konkrit. Dengan pendekatan pengertian hak penguasaan atas tanah sebagai lembaga hukum dan hubungan hukum konkrit, ketentuan-ketentuan hukum yang mengaturnya dapat disusun dan dipelajari dalam suatu sistematika yang khas dan masuk akal. Selain itu, dengan sistematika sebagai lembaga hukum dan hubungan hukum konkrit tersebut ketentuan-ketentuan hukum tanah bukan saja dapat diadakan, disusun, dan dipelajari secara teratur, tetapi juga akan dengan mudah diketahui ketentuan-ketentua apa yang termasuk hukum tanah dan apa yang bukan ${ }^{16}$.

Memperhatikan secara mendalam, UUPA menganut hak atas tanah yang bersifat terbuka. Artinya masih dimungkinkan terbentuknya bentuk-bentuk hak atas tanah kemudian selain yang telah diatur dalam UUPA, dengan mengingat perkembangan kehidupan bernegara. Hal tersebut ditegaskan dalam Pasal 16 ayat (1) huruf h UUPA, yang menyatakan bahwa hak-hak lain yang akan ditetapkan dengan undang-undang. Hal ini bisa dianalisis bahwa pembentuk UUPA pada waktu itu telah berfikir bahwa dikemudian hari atau pada suatu waktu yang akan datang akan lahir hak atas tanah yang baru seiring dengan perkembangan bernegara. Selanjutnya dalam hukum tanah terdapat pengaturan mengenai berbagai hak penguasaan atas tanah. Hal ini di dalam UUPA telah ditetapkan tata jenjang atau hierarki hak-hak penguasaan atas tanah, yaitu (Boedi Harsono, 2003:25-26):

1. Hak Bangsa Indonesia yang disebut dalam Pasal 1 UUPA sebagai hak penguasaan atas tanah yang tertinggi yang beraspek perdata dan publik;

2. Hak Menguasai Negara yang disebut dalam Pasal 2 UUPA sebagai hak penguasaan yang semata-mata mengandung aspek publik;

3. Hak Ulayat Masyarakat Hukum Adat yang disebut dalam Pasal 3 UUPA, yang beraspek perdata dan beraspek publik;

4. Hak-hak perseorangan/individu, yang semuannya berunsur perdata, terdiri atas: 1) hak-hak atas tanah sebagai hak individual yang semuannya secara langsung ataupun tidak langsung bersumber pada Hak Bangsa, yang disebut dalam Pasal 16 dan Pasal 53 UUPA;

5. Hak Ulayat Masyarakat Hukum Adat yang disebut dalam Pasal 3 UUPA, yang beraspek perdata dan publik;

14 Boedia Harsono, 2008. Hukum Agraria Indonesia Sejarah Pembentukan Undang-Undang Pokok Agraria, Isi dan Pelaksanaannya, PT Djambatan, Jakarta, hlm 18.

15 Boedi Harsosno, 2003. Hukum Agraria Indonesia Sejarah Pembentukan Undang-Undang Pokok Agraria, (isi dan Pelaksanaannya, Jilid 1 Hukum Tanah Nasonal, PT Djambatan, Jakarta, hal 23.

${ }^{16}$ Ibid. Boedi Harsono, 2003, hlm. 26-27. 
6. Hak-hak perorangan/individu, yang semuannya berunsur perdata, terdiri atas: 1) Hak-hak atas tanah sebagai hak individual yang semuannya secara langsung ataupun tidak langsung bersumber pada Hak Bangsa, yang disebut dalam Pasal 16 dan Pasal 53 UUPA; 2) Wakaf, yaitu Hak Milik yang sudah diwakafkan, Pasal 49 UUPA; 3) Hak jaminan atas tanah yang disebut hak tanggungan dalam Pasal 25, 33, 39, dan 51 UUPA serta UU No. 4 Tahun 1996. Oleh karena, Hak Bangsa merupakan Hak Penguasaan Atas tanah yang tertinggi di Indonesia, maka semua hak penguasaan atas tanah lainnya bersumberkan dari Hak Bangsa sebagai kekayaan bersama dari seluruh Bangsa Indonesia. Yang tunduk pada asas semua hak atas tanah berfungsi sosial.

Biarpun bermacam-macam hak penguasaan atas tanah, tetapi semua penguasaan hak atas tanah berisikan serangkaian wewenang, kewajiban dan/atau larangan bagi pemegang haknya untuk berbuat sesuatu mengenai tanah yang dihaki. Sesuatu yang boleh, wajib atau dilarang untuk diperbuat, yang merupakan isi hak penguasaan itulah yang menjadi kriterium atau tolak pembeda diantara hak-hak penguasaan atas tanah yang diatur dalam hukum tanah ${ }^{17}$.

Pasal 16 ayat (1) UUPA secara jelas menetapkan bentuk-bentuk hak atas yaitu:

1. Hak Milik;

2. Hak Guna Usaha;

3. Hak Guna Bangunan;

4. Hak Pakai;

5. Hak Sewa untuk Bangunan;

6. Hak Membuka Tanah;

7. Hak Memungut Hasil Hutan;

8. hak-hak lain yang akan ditentukan.

Berdasarkan bentuk-bentuk hak atas tanah, maka hak atas tanah dapat dibagi menjadi dua kelompok, yaitu ${ }^{18}$ :

1. Hak atas tanah yang bersifat primer.

Yaitu hak atas tanah yang berasal dari negara. Macam hak atas tanah ini adalah Hak Milik, Hak Guna Usaha, Hak Guna Bangunan atas tanah negara, dan Hak pakai atas tanah negara.

2. Hak atas tanah yang bersifat sekunder.

Yaitu hak atas tanah yang berasal dari pihak lain. Macam-macam hak atas tanah ini adalah Hak Guna Bangunan atas tanah Hak Pengelolaan, Hak Guna Bangunan Atas tanah Hak Milik, Hak Pakai atas tanah Hak Pengelolaan, Hak Pakai atas Tanah Milik, Hak Sewa Bangunan, Hak Gadai, Hak Usaha Bagi Hasil, Hak Numpang, dan Hak Sewa Tanah Pertanian.

Bentuk-bentuk hak atas tanah yang telah diuraikan tersebut di atas salah satunya adalah hak milik. Jika ditelaah secara normatif hak milik atas tanah diposisikan sebagai hak atas tanah yang bersifat primer yang menurut Urip Santoso hak tersebut dimasukkan juga dalam hak atas tanah yang bersifat tetap ${ }^{19}$. Hak milik atas tanah merupakan hak primer yang paling utama, terkuat dan terpenuh, dibandingkan dengan hak-hak primer lainnya, seperti hak guna usaha, hak guna bangunan, hak pakai atau hak-hak lainnya ${ }^{20}$. Pengertian hak milik dalam Pasal 20 ayat (1) UUPA yakni, "hak milik adalah hak turun temurun, terkuat, dan terpenuh, yang dapat dipunyai orang atas tanah dengan mengingat ketentuan Pasal 6".

Berdasarkan pengertian tersebut, dapat dijelaskan sifat dari hak milik ${ }^{21}$ yaitu:

1. Turun temurun adalah hak milik atas tanah dapat berlangsung terus selama pemiliknya masih hidup dan dapat dilanjutkan oleh ahli waris.

2. Terkuat adalah hak milik atas tanah lebih kuat dibandingkan dengan hak atas tanah lain, tidak mempunyai batas waktu tertentu, mudah dipertahankan dari gangguan pihak lain, dan tidak mudah hapus ${ }^{22}$.

3. Terpenuh adalah hak milik atas tanah memberi wewenang kepada pemiliknya paling luas bilah dibandingkan dengan hak atas tanah yang lain, dapat menjadi induk bagi hak atas tanah yang lain, tidak berinduk pada hak atas tanah yang lain. Penjelasan senjutnya bahwa sifat terpenuh, artinya hak milik memberi wewenang kepada pemiliknya paling luas bila dibandingkan dengan hak atas tanah yang lain, dapa menjadi induk bagi hak atas tanah

${ }^{17}$ Boedi Harsono, 2008, hlm 24.

${ }^{18}$ Ibid Urip Santoso, 2014, hlm 34.

${ }^{19}$ Ibid Urip Santoso, 2017, hal 10.

${ }^{20}$ Supriadi, 2010. Hukum Agraria, PT Sinar Grafika, Jakarta hlm 54.

21 Urip Santoso. 2017. Hak Atas Tanah, Hak Pengelolaan, \& Hak Milik Atas Satuan Rumah Susun, PT Kencana, Cimanggis hlm 67.

${ }^{22}$ I Gusti Nyoman Yonatan Wiradi, dkk. Peran PPATK Dalam Mencegah Pemilikan Secara Absentee Melalui Jual-Beli Hak Milik Tanah Pertanian, Jurnal Hukum Justitia Et Pax, Vol. 34, No. 1, 2018, hlm 122. 
yang lain, tidak tunduk pada hak atas tanah yang lain, dan penggunaan tanahnya lebih luas bila dibandingkan dengan hak atas tanah yang lain. Hak milik dapat menjadi induk bagi hak atas tanah yang lain yaitu di atas tanah hak milik dapat lahir hak atas tanah berupa hak guna bangunan, hak pakai dan hak sewa untuk bangunan ${ }^{23}$.

Mengenai subjek hak milik disebutkan dalam Pasal 21 UUPA, yakni:

1. Hanya warga negara Indonesia dapat mempunyai hak milik;

2. Oleh pemerintah ditetapkan badan-badan hukum yang dapat mempunyai hak milik dengan syarat-syaratnya;

3. Orang asing sesudah berlakunya undang-undang ini memperoleh hak milik wajib melepaskan hak itu di dalam jangka waktu satu tahun sejak diperolehnya hak tersebut atau hilangnya kewarganegaraan itu. Jika sesudah jangka waktu tersebut lampau hak milik itu tidak dilepaskan, maka hak itu hapus karena hukum dan tanahnya jatuh kepada negara, dengan ketentuan hak pihak lain yang membebaninya tetap berlangsung;

4. Selama seseorang disamping kewarganegaraan Indonesianya mempunyai kewarganegaraan asing, maka ia tidak mempunyai tanah dengan hak milik dan baginya berlaku ketentuan dalam ayat 3 pasal ini.

Menurut Urip Santoso ${ }^{24}$ subjek hukum yang dapat mempunyai hak milik atas tanah, adalah: a) Perseorangan: hanya warga negara Indonesia yang dapat mempunyai hak milik atas tanah. b) Badan Hukum: badan-badan hukum yang dapat mempunyai hak milik atas tanah, yaitu bank-bank yang didirikan oleh negara, koperasi pertanian, badan keagamaan, dan badan sosial.

Selanjutnya terjadinya hak milik atas tanah diatur dalam Pasal 22 UUPA. Ada tiga cara terjadinya hak milik ${ }^{25}$, yaitu:

1. Hak milik atas tanah terjadi menurut hukum adat. Ada dua cara terjadinya hak milik menurut hukum adat, yaitu: a) Pembukaan tanah (pembukaan hutan); b) Timbulnya lida tanah. Hak milik dalam hukum adat yaitu hak komunal yang merupakan hak milik bersama masyarak hukum adat ${ }^{26}$.

2. Hak milik atas tanah terjadi karena penetapan pemerintah. Hak milik atas tanah ini terjadi melalui permohonan pemberian hak atas tanah negara atau tanah yang dikuasai langsung oleh negara.

3. Hak milik atas tanah terjadi karena ketentuan undang-undang. Hak milik atas tanah ini terjadi sejak sebelum diundangkannya UUPA, hak-hak tersebut dapat dikonversi menjadi hak milik dengan memenuhi syarat-syarat yang ditentukan dalam peraturan perundang-undangan yang berlaku.

Peralihan hak milik atas tanah diatur dalam Pasal 20 ayat (2) UUPA, yakni "hak milik dapat beralih dan dialihkan kepada pihak lain. Kemudian hak milik ini sesuai dengan Pasal 25 UUPA dapat dijadikan objek hak tanggungan, dan dari hak milik ini dimungkinkan diikat suatu perjanjian hak pakai/hak guna bangunan atasnya ${ }^{27}$. Peralihan hak milik atas tanah dalam UUPA terdapat dua (2) bentuk peralihan ${ }^{28}$, yakni beralih dan dialihkan/pemindahan hak. Beralih dan dialihkan hak milik atas tanah diuraikan berikut:

1. Beralih yang dimaksudkan, berpindahnya hak atas tanah dari pemegang haknya kepada pihak lain karena pemegang haknya meninggal dunia atau melalui pewarisan. Peralihan hak atas tanah ini terjadi karena hukum.

2. Dialihkan/pemindahan hak. Yang dimaksud misalnya berpindanya hak atas tanah dari pemegang haknya kepada pidak lain karena suatu perbuatan hukum yang sengaja dilakukan dengan tujuan agar pihak lain tersebut memperoleh hak tersebut, berupa jual-beli, tukar-menukar, hibah, penyertaan dalam modal perusahaan.

Hapusnya hak milik atas tanah diatur dalam Pasal 27 UUPA, yang menyatakan bahwa hak milik hapus bila:

1. Tanahnya jatuh kepada negara:

a. Karena pencabutan hak berdasarkan Pasal 18 UUPA. Pasal 18 UUPA menyatakan: Untuk kepentingan umum, termasuk kepentingan bangsa dan negara serta kepentingan bersama dari rakyat, hak-hak atas tanah dapat dicabut, dengan memberi ganti kerugian yang layak dan menurt cara yang diatur dengan undang-undang. Pencabutan hak atas tanah yang dimaksudkan termasuk juga hak milik atas tanah sesuai dengan ketentuan yang berlaku. Sebagaimana cara memperoleh, dan pemberian ganti rugi yang layak dan adil.

${ }^{23}$ Urip Santoso, Pembebanan Hak Sewa Untuk Bangunan Atas Tanah Hak Milik: Perspektif Asas Dan Pembuktian, Jurnal Yuridika, Volume 33, Nomor 2, 2018 hlm 333

${ }^{24}$ Ibid Urip Santoso, 2012, hlm 51.

25 Bambang Eko Supriyadi, 2014. Hukum Agraria Kehutanan (Aspek Hukum Pertanahan dalam Pengelolaan Hutan Negara), PT Radjagrafindo Persada, Jakarta hlm 18.

${ }^{26}$ Sahrina Safiuddin, 2018. Hak Ulayat Masyarakat Hukum Adat dan Hak Menguasai Negara di Taman Nasional Rawa Aopa Watumohai, Jurnal Mimbar Hukum Volume 30, Nomor 1, Februari 2018.

${ }^{27}$ A.P. Parlindungan, 2008. Komentar Atas Undang-Undang Pokok Agraria, PT Mandar Maju, Bandung hlm 68.

${ }^{28}$ Boedi Harsono, 2008, hlm 80. 
b. Karena penyerahan dengan sukarela oleh pihak pemiliknya. Cara ini berarti hak milik jatu kepada negara karena yang berhak secara sukarela menyerahkan tanahnya yang berstatus hak milik itu kepada negara. Dengan demikian, jatuhnya tanah hak milik menajdi tanah yang dikuasai langsung oleh negara.

c. Karena ditelantarkan. Ketentuan Pasal 27 UUPA menyatakan, "tanah ditelantarkan kalau dengan sengaja tidak dipergunakan sesuai dengan keadaannya atau sifat dan tujuan daripada haknya.

d. Karena ketentuan Pasal 21 ayat (3) dan Pasal 26 ayat (2) UUPA. Pasal 21 ayat (3) UUPA menyatakan "orang asing sesudah berlakunya undang-undang ini mempunyai hak milik karena pewarisan-tanpa wasiat atau yang mempunyai hak milik dan setelah berlakunya undang-undang ini kehilangan kewarganegaraannya wajib melepaskan hak itu dalam jangka waktu satu tahun sejak diperolehnya hak tersebut atau hilangnya kewarganegaraan itu. Jika sesudah jangka waktu tersebut lampau hak milik itu tidak dilepaskan, maka hak tersebut hapus karena hukum dan tanah jatuh kepada negara, dengan ketentuan bahwa hak-hak pihak lain yang membebaninya tetap berlangsung. Ketentuan ini merupakan pelaksanaan dari asas nasionalitas yang dianut oleh UUPA.

2. Tanahnya Musnah

Secara konseptual, sesuatu hak atas tanah harus dipenuhi secara komulatif yaitu adanya subjek hak yang memenuhi syarat, dan objek hak yang sah dalam hubungan hukum. Sehingga jika tanahnya musnah berarti salah satu dari unsur hak itu yaitu objek haknya sudah tidak ada lagi. Konsekwensinya, hak itu hilang dengan sendirinya. Tanahnya musnah dikategorigakn karena diluar kemampuan manusia misalnya bencana alam.

3. Pembuktian

Mengenai pembuktian hak milik atas tanah sering terjadi perdebatan dalam praktek sehari-hari. Pemerintah selalu berpedoman pada pembuktian melalui sertifikat hak atas tanah atau telah mendapat pengakuan secara tertulis dari instandi/lembaga ata badan pemerintah dalam hal ini adalah Badan Pertanahan Nasional, berbeda dengan pembuktian menurut masyarakat pedesaan yaitu dengan adanya keputusan dari aparat pemerintah desa atau lurah. Mengenai tata cara perolehan hak atas tanah yang diakui oleh negara berpedoman pada Peraturan Pemerintah Nomor 24 Tahun 1997 tentang Pendaftaran Hak atas Tanah. Kalaupun ditelah secara seksama menegenai tata cara perolehan dan pendaftaran tanah hak milik disebutkan secara lengkap. Untuk memperoleh sertifikat hak kepemilikan atas tanah, terlebih dahulu harus dipenuhi beberapa persyaratan yang harus dipenuhi oleh pemohon. Akan tetapi sebagaimana penjelasan Pasal 32 ayat (1) Peraturan Pemerintah Nomor 24 Tahun 1997 menegaskan bahwa sertifikat merupakan tanda bukti yang kuat selama tidak dapat dibuktikan sebaliknya data fisik dan data yuridis yang tercantum di dalamnya diterima sebagai data yang benar. ini dapat disimpulkan bahwa sertifikat sebagai produk lembaga pemerintah ada kemungkinan tidak benar (terlepas dari sebab-sebabnya), dengan demikian dapat mengurangi arti kepastian hukum sertifikat itu sendiri ${ }^{29}$.

Berikutnya dalam peraturan tersebut menegaskan bahwa sertifikat merupakan alat bukti hak yang kuat. Dalam Peraturan Pemerintah Nomor 24 Tahun 1997 menganut stelsel negatif yang mengandung unsur positif karena akan melahirkan surat-surat tanda bukti hak yang berlaku sebagai alat pembuktian yang kuat sebagaimana dinyatakan dalam UUPA ${ }^{30}$. Yang dimaksud dengan alat bukti hak yang kuat dalam hal ini adalah bahwa selama tidak dapat dibuktikan sebaliknya, data fisik dan data yuridis yang tercantum di dalam alat bukti itu harus diterima sebagai data yang benar. Agar sertifikat hak milik atas tanah dapat dijadikan sebagai alat bukti hak yang kuat maka, dalam proses penerbitan sertifikat tersebut harus melalui prosedur dan ketentuan peraturan perundang-undangan yang berlaku ${ }^{31}$. Namun demikian, kebenaran sertifikat masih tetap terbuka untuk dibantah mengingat stelsel publikasi dari pendaftaran tanah yang dianut Indonesia adalah stelsel negatif, yang kebenaran data yang disajikan tidak dijamin oleh negara. Sebagaimana ditegaskan dalam penjelasan Pasal 32 ayat (2) Peraturan Pemerintah Nomor 24 Tahun 1997 menyatakan bahwa pihak yang namanya tercantum sebagai pemegang hak dalam buku tanah dan sertifikat selalu menghadapi kemungkinan gugatan dari pihak lain yang merasa mempunyai hak atas tanah tersebut.

Berdasarkan konsep tersebut di atas kiranya memperjelas hak milik atas tanah sebagaimana yang dimaksudkan dalam UUPA, baik dari aspek filosofi dan konsep yang tertuang di dalamnya sehingga sangatlah penting dan wajib dalam pembentukan setiap regulasi yang berkaitan dengan hak milik atas tanah, untuk tidak keluar dari apa yang terkandung di dalamnya.

${ }^{29}$ Indri Hadisiswati, Kepastian Hukum Dan Perlindungan Hukum Hak Atas Tanah, Jurnal AHKAM, Volume 2, Nomor 1, Juli 2014, hlm 211.

${ }^{30}$ Lisa Mayanti Famaldina, Implikasi Hukum Keterlambatan Pendaftaran Akta Peralihan Hak Atas Tanah ( Studi di Kantor Pertanahan Kabupaten Bima), Jurnal IUS Hukum Dan Keadilan, Volume, 4, Noomor 3, 2016, hlm

${ }^{31}$ Dadi Arja Kusuma, dkk, Sertifikat Hak Atas Tanah Sebagai Alat Bukti Yang Kuat, Jurnal IUS, Volume V, nomor 2 , 2017, Hlm 312. 
GMIH merupakan badan hukum yang bergerak dalam bidang keagamaan pada umumnya yang didirikan dengan akta Nomor: 10 tertanggal 31 Agustus 1998. Berdasarkan pendirian badan hukum GMIH, Badan Pertanahan Nasional telah mengeluarkan Surat Keputusan Nomor 5-VIII-1998 Tentang Penunjukan GMIH Sebagai Badan Hukum Yang Dapat Mempunyai Tanah Dengan Hak Milik. Penunjukan badan hukum dapat mempunyai hak milik atas tanah, berdasarkan ketentuan Pasal 21 ayat (2) UUPA sebagaimana di atur pulah dalam Peraturan Pemerintah Nomo 38 Tahun 1963 Tentang Penunjukan Badan-Badan Hukum Yang Dapat Mempunyai Hak Milik Atas Tanah, intinya menetapkan bahwa badan-badan hukum dapat mempunyai hak atas tanah. Yang selanjutnya ditegaskan pula dalam Pasal 49 UUPA bahwa sepanjang dipergunakan untuk usaha dalam bidang sosial dan keagamaan diakui dan dilindungi.

Penetapan GMIH sebagai badan hukum yang mempunyai hak milik atas tanah memberikan wewenang untuk menguasasi, mengelola dan mengatur peruntukannya. Dalam pelaksanaannya Peraturan GMIH Tahun 2003 Khusus Pembagian Tanah Perkebunan GMIH Bagi Pegawai Organik/Pensiunan Untuk Lokasi Perumahan Di Wari Dan Wosia (selanjutnya disingkat Peraturan GMIH Tahun 2003), secara lengkap menyebutkan ketentuan-ketentuan mengenai hak milik atas tanah khususnya yang telah diserahkan ke pegawai organik/pensiuna. Sebelumnya yang dimaksud pegawai organik dalam Peraturan GMIH tahun 2003 adalah orang-orang yang bekerja pada GMIH yang diangkat berdasarkan Peraturan Gereja. Kalaupun ditelaah secara seksama bahwa ketentuan yang diatur dalam Peraturan GMIH tahun 2003 tersebut merupakan peraturan khusus (lexs specialis) yang mengatur khususnya tentang tanah-tanah GMIH yang akan diserahkan kepada pegawai organik. Pemberian tanah GMIH kepada pegawai organik adalah merupakan pelaksanaan dari ketentuan mengani hak dan kewajiban pegawai. Hal tersebut ditegaskan dalam Pasal 6 ayat (2) Peraturan GMIH tahun 2003 yang menyatakan bahwa setiap peserta (pegawai organik/pensiunan) berhak mendapat satu bagian tanah kapling dengan ukuran $15 \times 30 \mathrm{~m} 2$. Dalam peraturan tersebut ditetapkan syarat-syarat yang dapat menerima penyerahan hak atas tanah. Syarat-syarat yang dimaksudkan adalah:

1. Yang dapat menerima atau penyerahan hak atas tanah dari GMIH adalah mereka yang berstatus pegawai organik/pensiunan.

2. Membayar uang Rp 10.000.000 (sepuluh juta rupiah) sebagai bentuk ganti rugi kepada GMIH dengan ukuran 25x30 meter, hal tersebut ditegaskan sebagaimana pada Pasal 8 ayat (1) hurut a Peraturan GMIH Tahun 2003.

3. Menyerahan tanah tersebut kemudian tidak bisa dialihkan (jual-beli, tukar-menukar, hibah dan mengadaikan) kepada pihak lain, berlaih bisa terjadi karena hanya pewarisan.

Bahwa kalaupun ditelah dari aspek hukum jual-beli, maka penyerahan hak atas tanah GMIH kepada pegawai organik yang dimaksudkan adalah melalui jual-beli dengan persayaratan khusus bagi pegawai organik. Hal ini ditegsakan dalam Pasal 5 ayat (3) yakni mekanisme dan proses kepemilikan diatur sebagai berikut:

1. Membuat surat permohonan kepada GMIH, membuat surat perjanjian (tidak mengalihkan ke pihak lain), bukti sebagai pegawai organik;

2. Membayar biaya pendaftaran;

3. Membayar biaya ganti rugi yang telah ditetapkan (10.000.000);

4. Penyerahan SK Penyerahan Hak Kepemilikan Dari GMIH ke pegawai organik. Dengan demikian status hak atas tanah yang telah diserahkan adalah jual-beli yang dikususkan bagi pegawai organik, sehingga satus penguasaan hak pegawai organik adalah hak milik atas tanah.

Sebagaimana hasil wawancara dengan Pegawai Badan Usaha Milik Gereja (BUMG) Pendeta Tot Duan, menjelaskan bahwa mengenai ketentuan mengalihkan atau beralih yaitu tanah-tanah yang telah diserahkan kepada pegawai organik atau pensiunan memang demikian tidak bisa kemudian dijual, atau ditukar, dijaminkan. Untuk pewarisan dapat dibenarkan dalam garis keturunan menyamping dan garis keturunan ke bawah. Dan itu telah dilakukan selama ini ${ }^{32}$. Mengenai larangan mengalihkan hak milik atas tanah yang berasal dari tanah GMIH, untuk lebih jelasnya dibahas pada sub bab selanjutnya.

\section{Ketentuan Larangan Pengalihan Hak Milik Atas Tanah Gereja Dan Kepastian Hukum Pemegang Hak}

GMIH merupakan badan hukum yang bergerak dalam bidang keagamaan pada umumnya yang didirikan dengan akta Nomor: 10 tertanggal 31 Agustus 1998, yang tunduk di bawah Yayasan GMIH. Singkatnya aset GMIH khususnya tanah adalah bekas perusahan perkebunan peninggal Belanda,yang kini telah menjadi milik Yayasan GMIH. Berdasarkan Keputusan Menteri Negara Agraria/Kepala Badan Pertanahan Nasonal Nomor 5-VIII-1998 Tentang Penunjukan GMIH Sebagai Badan Hukum Yang Dapat Mempunyai Tanah Dengan Hak Milik ${ }^{33}$.

\footnotetext{
${ }^{32}$ Wawancara dengan Pendeta Tot Duan salah satu pegawai BUMG-GMIH.

${ }^{33}$ Hasil Wawancara dengan Biro Hukum GMIH , tanggal 3/06/2020.
} 
Dalam GMIH ditentukan khusus biro yang membidangi aset-aset termasuk tanah, yaitu Badan Usaha Milik GMIH (BUMG). Saat ini Pdt Rudi Tindage ditetapkan sebagai direktur BUMG-GMIH. Berdasarkan hasil wawancara dengan Direktur BUMG-GMIH Pdt Rudi Tindage, M.Teol menjelaskan bahwa penyerahan hak atas tanah terhadap pegawai organik telah diatur dalam peraturan khusus, yaitu Peraturan GMIH Tahun 2003 Khusus Pembagian Tanah Perkebunan GMIH Bagi Pegawai Organik/Pensiunan Untuk Lokasi Perumahan Di Wari Dan Wosia. Mengenai penyerahan hak atas tanah kepada pegawai organik/pensiunan adalah merupakan sebagai bentuk penghargaan terhadap jasanya dalam tugas dan pelayanannya dibidang keagamaan GMIH, sehingga jasa yang diberikan tidak bisa dialikan maupun perbuatan lain karena itu sudah menjadi aturan GMIH yang diberlakukan, tidak bisa dijadikan dengan tujuan komersial. Karena itu bertentangan sifat dan tujuan pemberian hak yang sesungguhnya ${ }^{34}$. Kalaupun kedapatan ada perbuatan mengalihakan tanah yang berasalah dari tanah GMIH, maka konsekwensinya adalah GMIH sebagai pemilik awal akan menarik kembali dengan segala akibat yang tidak ditanggung oleh GMIH. Larangan pemindahan hak milik atas tanah dalam Peraturan GMIH Tahun 2003 tersebut, bertolak dari konsep teologi yang dianut oleh GMIH adalah Tanah GMIH merupakan milik Tuhan Yesus sebagai Sang Kepala Gereja jadi harus diatur dan diolah sendiri. Hal ini yang mendasari larangan pengalihan tanah GMIH yang telah diserahkan ke pegaia organik.

Penyerahan hak atas tanah GMIH ke pegawai organik adalah penyerahan hak melalui jual beli. Hal ini terdapat pada Pasal 8 Peraturan GMIH tahun 2003, yakni penetapan harga tanah kaplingan Rp 10.000.000 dengan metode pembayaran dua (2) kali angsuran sebesar Rp 5.000.000. Mekanismenya dan proses kepemilikan diatur dalam Pasal 5 ayat (3), sebagai berikut:

1. Membuat surat permohonan kepada GMIH, membuat surat perjanjian (tidak mengalihkan ke pihak lain), bukti sebagai pegawai organik;

2. Membayar biaya pendaftaran;

3. Membayar biaya ganti rugi yang telah ditetapkan (10.000.000);

4. Penyerahan SK Penyerahan Hak Kepemilikan Dari GMIH ke pegawai organik.

Penyerahan hak tersebut merupakan perbuatan hukum jual-beli yang dimaksudkan sebagaimana dalam praktek yang ditegaskan misalnya Putusan Mahkamah Agung No.123/K/Sip/Pdt/1970 menyebutkan bahwa syarat material sahnya penyerahan hak atas tanah: pertama, penjual berhak memindahkan hak milik; kedua, pembeli berhak menerima hak; ketiga, tanah dapat diperjualbelikan dan keempat, tanah tidak dalam sengketa.

Berbeda dalam pelaksanaan peraturan GMIH tersebut tidak memberikan jaminan kepastian hukum sebagaimana hak milik yang dimaksudkan UUPA. Ketentuan larangan yang dimaksudkan ialah mengandung konsep teologi (agama) yang berbeda dengan konsep religius yang dimaksudkan UUPA. Unsur-unsur agama dalam UUPA Pasal 1 ayat (2) intinya menegaskan bahwa seluruh bumi, air dan ruang angkasa dan kekayaan alam yang terkandung di dalamnya sebagai karunia Tuhan Yang Mahas Esa. Sehingga konsep teologi yang mendasarkan adanya ketentuan larangan pengalihan hak milik atas tanah GMIH mengabaikan unsur kepastian dan perlindungan sebagaimana tujuan UUPA.

Pembahasan sebelumnya adalah bagian yang saling berkaitan dengan sub pembahasan ini, jika dikolerasikan dengan ketentuan larangan pemindahan hak milik yang diatur oleh UUPA terdapat perbedaan yang sangat mendasar. Hal mana bahwa menurut ketentuan UUPA peralihan hak milik atas tanah diatur dalam Pasal 20 ayat (2) UUPA, yakni "hak milik dapat beralih dan dialihkan kepada pihak lain. Kemudian hak milik ini sesuai dengan Pasal 25 UUPA dapat dijadikan objek hak tanggungan, dan dari hak milik ini dimungkinkan diikat suatu perjanjian hak pakai/hak guna bangunan atasnya. Peralihan hak milik atas tanah dalam UUPA terdapat dua (2) bentuk peralihan, yakni beralih dan dialihkan/pemindahan hak. Beralih dan dialihkan hak milik atas tanah diuraikan berikut ${ }^{35}$ :

1. Beralih yang dimaksudkan, berpindahnya hak atas tanah dari pemegang haknya kepada pihak lain karena pemegang haknya meninggal dunia atau melalui pewarisan. Peralihan hak atas tanah ini terjadi karena hukum.

2. Dialihkan/pemindahan hak. Yang dimaksud misalnya berpindanya hak atas tanah dari pemegang haknya kepada pidak lain karena suatu perbuatan hukum yang sengaja dilakukan dengan tujuan agar pihak lain tersebut memperoleh hak tersebut, berupa jual-beli, tukar-menukar, hibah, penyertaan dalam modal perusahaan.

Perbuatan-perbuatan tersebut dimungkinkan dilakukan oleh pemilik tanah sepanjang tidak dilarang atau bertentangan dengan ketentuan yang telah diatur dalam UUPA. Bersamaan di dalamnya untuk memberikan jaminan kepastian hukum bagi pemegang hak milik atas tanah. Ketentuan perbuatan pemindahan hak milik atas tanah yang dilarang diatur dalam Pasal 26 UUPA ayat (2), yang menyatakan bahwa "setiap jual-beli, penukaran, penghibahan, pemberian dengan wasiat dan perbuatan-perbuatan lain yang dimaksudkan untuk langsung atau tidak langsung

${ }^{34}$ Hasil Wawancara tanggal 7/06/2020.

${ }^{35}$ I Gusti Nyoman Yonatan Wiradi, dkk. Peran PPATK Dalam Mencegah Pemilikan Secara Absentee Melalui Jual-Beli Hak Milik Tanah Pertanian, Jurnal Hukum Justitia Et Pax, Vol. 34, No. 1, 2018, hlm 123. 
mindahkan hak milik kepada orang asing, kepada seorang warga negara yang disamping kewarganegaraan Indonesiannya mempunyai kewarganegaraan asing atau kepada suatu badan hukum, kecuali yang ditetapkan oleh Pemerintah termasuk dalam Pasal 21 ayat (2) adalah batal karena hukum dan tanahnya jatuh kepada negara, dengan ketentuan, bahwa hak-hak pihak lain yang membebaninya tetap berlangsung serta semua pembayaran yang telah diterima oleh pemilik tidak dapat dituntu kembali”.

Kalaupun dicermati secara saksama ketentuan Pasa 26 ayat (2) UUPA tersebut, pemindahahan hak milik yang bertentangan dengan ketentuan tersebut akan berakibat hukum, yakni:

1. Perbuatan pemindahan hak itu batal karena hukum, sehingga tidak diperlukan pernyataan hakim;

2. Tanahnya jatuh pada negara, yang berarti hak miliknya menjadi hapus dan hapusnya hak milik itu tidak memerlukan keputusan hakim;

3. Semua pembayaran yang telah diterima pemilik tidak dapat dituntut kembali.

Hal ini dapat dikatakan sebagai ketentuan khusus dari UUPA. Suatu perbuatan sebagai perbuatan yang batal karena hukum, artinya dengan sendirinya batal tanpa harus mengajukan permohonan pembatalan ke lembaga yang berwenang untuk itu, maka konsekwensinya segala sesuatu kembali pada keadaan atau kedudukan yang semula.

Ditegaskan Urip Santoso, untuk melakukan suatu perbuatan hukum peralihan hak atas tanah (termasuk hak milik atas tanah) setiap subjek hukum harus memenuhi syarat materi dan syarat formil sebagai subjek. Syarat materil dimaksudkan bahwa pihak yang mengalihkan hak atas tanah berhak dan berwenang, sedang untuk pemenerima hak atas tanah harus memenuhi sayart sebagai subjek hak. Mengenai syarat formal setiap peralihan hak atas tanah harus dibuktikan dengan akta-akta (akta di bawah tangan dan akta autentik) yang ditentukan peraturan perundang undangan $^{36}$.

Bahwa penentuan syarat-syarat yang dimaksudkan tersebut di atas adalah menghindari setiap perbuatan pengalihan hak milik atas tanah tidak bertentangan dengan asas yang dianut UUPA, yakni asas nasionalitas menyatakan bahwa hanya warga negara Indonesia saja yang dapat mempunyai hak milik atas tanah ${ }^{37}$ atau yang boleh mempunyai hubungan hukum dengan bumi dan ruang angkasa dengan tidak membedakan antara laki-laki dan perempuan serta sesama warga negara baik asli maupun keturunan. Asas nasionalitas dirumuskan dalam Pasal 21 ayat (1) adalah hanya warga negara Indonesia yang dapat mempunyai hak milik. maka sepanjang perbuatan-perbuatan hukum atau peralihan hak milik atas tanah tersebut tidak bertentangan dengan UUPA maka perbuatan hukum peralihan hak milik atas tanah tersebut adalah sah dan mengikat.

\section{SIMPULAN}

Berdasarkan uraian-uraian sebelumnya, maka dapat diambil sebuah kesimpulan, sebagai berikut: pertama peraturan GMIH tentang hak milik dan hubungannya dengan konsep hak milik dalam UUPA berbeda. Dimana ketentuan GMIH yang mengatur tentang pembagian atau penyerahan tanah yang kemudian berstatus hak milik terhadap pegawai organik atau pensiunan, mengandung konsep teologi yang berakibat pada batasan penggunaan tanah hak milik GMIH. Bahwa hal tersebut secara jelas bertolak belakang dengan konsep hak milik yang dimaksudkan UUPA. Kedua, dalam pelaksanaannya subjek hak milik atas tanah yang tanah hak miliknya berasal dari GMIH, tidak ada jaminan perlindungan dan kepastian hukum, dan secara tidak langsung ketentuan GMIH telah merampas subjek pemegang hak milik atas tanah. Dimana tanah dengan status hak milik menurut UUPA wewenangnya sangat luas dan penuh terlebih khusus dalam perbuatan mengalihkan atau melakukan perbuatan hukum Berikutnya untuk badan hukum GMIH sendiri ketika berperkara ke pengadilan akan terjadi peluang besar dikesampingkannya ketentuan tanah GMIH unsur khusus dalam mengatur tanah gereja. Hal tersebut sesungguhnya sangat dalam pelaksanaannya bertentangan dengan jiwa UUPA.

Mengacu pada kesimpulan tersebut di atas maka dapat di berikan saran pertama, untuk keharmonisan norma antara peraturan GMIH tentang tanah, maka perluh penyesuaian dengan mengacu pada konsep hak milik sebagaimana telah ada dalam UUPA, dan itu dirumuskan pada peraturan konkret. Kedua, untuk menjamin kepastian hukum dan perlindungan hukum baik bagi GMIH sebagai badan hukum dan pegawai organik/pensiunan sebagai subjek orang perorangan, maka peraturan GMIH tersebut harus sesuai dengan amanat UUPA sebagai induk dari hukum pertanahan Indonesia yang kemudian menjadi dasar pembetukan hukum yang ada di bawahnya.

\footnotetext{
${ }^{36}$ Ibid Urip Santoso, 2014, hlm 368-369.

${ }^{37}$ Jum Anggriani, Penerapan Asas Nasionalitas Dalam Peraturan Perundang-Undangan Agraria Indonesia (Studi Kasus PP No. 40 Tahun 1996), Jurnal Dinamika Hukum, Vol 12, No. 1, 2012 hlm 176.
} 
Reli Jevon Laike, Kajian Hukum Agraria terhadap Ketentuan Larangan Pengalian Hak Milik atas Tanah Gereja (Studi Kantor Sinode Gereja Masehi Injili di Halmahera)

\section{DAFTAR PUSTAKA}

\section{Buku}

A.P. Parlindungan. Komentar Atas Undang-Undang Pokok Agraria. Bandung: PT Mandar Maju, 2008.

Bambang Eko Supriyadi. Hukum Agraria Kehutanan (Aspek Hukum Pertanahan dalam Pengelolaan Hutan Negara), Jakarta: PT Radjagrafindo Persada, 2014.

Boedi Harsono. Hukum Agararia Indonesia (sejarah pembentukan Undang-Undang Pokok Agraria dan Peraturan Pelaksana). Jakarta: PT Djambatan, 2008.

Moh. Mahfud. Politik Hukum Di Indonesia. Jakarta: PT Raja Grafindo Persada, 2011.

Sudikno Mertokusumo. Mengenal Hukum Suatu Pengantar. Yogyakarta: PT Liberty, 2012.

Supriadi. Hukum Agraria, Jakarta:PT Sinar Grafika, 2010.

Urip Santoso. Pendaftaran Dan Peralihan Hak Atas Tanah, Jakarta: PT Kencana, 2014.

Hak Atas Tanah, Hak Pengelolaan, \& Hak Milik Atas Satuan Rumah Susun. Cimanggis: PT Kencana, 2017.

2012. Hukum Agraria Kajian Komprehensif. Jakarta: PT Kencana, 2012.

\section{Jurnal}

Budi Sastra Panjaitan. "Pembentukan Pengadilan Pertanahan Sebagai Solusi Penyelesian Sengketa Pertanahan", Jurnal Bina Hukum Lingkungan, Vol 4 No. 1, 2020 : 269.

Dadi Arja Kusuma., "Sertifikat Hak Atas Tanah Sebagai Alat Bukti Yang Kuat", Jurnal IUS Hukum Dan Keadilan, Vol. 5, No 2, 2017: 312.

Indri Hadisiswati., "Kepastian Hukum Dan Perlindungan Hukum Hak Atas Tanah", Jurnal AHKAM: Ilmu Syariah, Vol. 2, No 1, (Juli, 2014): 211

Igusti Nyoman Yonatan Wiradi, dkk., "Peran PPATK Dalam Mencegah Pemilikan Secara Absentee Melalui Jual-Beli Hak Milik Tanah Pertanian", Jurnal Hukum Justitia Et Pax, Vol. 34, No. 1, 2018: 122

Jum Anggriani., "Penerapan Asas Nasionalitas Dalam Peraturan Perundang-Undangan Agraria Indonesia (Studi Kasus PP No. 40 Tahun 1996)", Jurnal Dinamika Hukum, Vol 12, No. 1, 2012: 176.

Lisa Mayanti Famaldina., Implikasi Hukum Keterlambatan Pendaftaran Akta Peralihan Hak Atas Tanah ( Studi di Kantor Pertanahan Kabupaten Bima), Jurnal IUS Hukum Dan Keadilan, Vol. 4, No. 3, 2016.

Muhammad Jefrry Maulidi., “Analisis Hukum Tentang Peralihan Hak Milik Atas Tanah Dengan Bukti Akta Di Bawah Tangan Sebagai Dasar Pendaftaran Tanah Untuk Pertama Kali (Studi Di Kabupaten Lombok Tengah)”, Jurnal Kajian Hukum Dan Keadilan, Vol. 5, No. 3, 2017:419.

Sahrina Safiuddin., Hak Ulayat Masyarakat Hukum Adat dan Hak Menguasai Negara di Taman Nasional Rawa Aopa Watumohai, Jurnal Mimbar Hukum, Vol. 30, No. 1, 2018.

Urip Santoso., Pembebanan Hak Sewa Untuk Bangunan Atas Tanah Hak Milik: Perspektif Asas Dan Pembuktian, Jurna Yuridika, Vol. 33, No. 2, 2018: 51.

\section{Peraturan Perundang-Undangan}

Undang-Undang Dasar Negara Republik Indonesia Tahun 1945.

Undang-Undang Nomor 5 Tahun 1960 Tentang Pokok-Pokok Agraria, 2008, PT Pradnya Paramita, Jakarta.

Peraturan Pemerinta Nomor 24 Tahun 1997 Tentang Pendaftaran Tanah.

Peraturan Khusus Pembagian Tanah Perkebunan GMIH Bagi Pegawai Organik/Pensiunan Untuk Lokasi Perumahan Di Wari Dan Wosia Tahun 2003

\section{Dokumen Lain}

Hasil Wawancara Dengan Pdt Rudi Tindage selaku Direktur BUMG-GMIH tanggal 28/02/2020.

Hasil Wawancara Dengan Pdt Tot Duan selaku Pegawai BUMG-GMIH tanggal 14/03/2020.

Hasil Wawancara Dengan Gilbert,S.H selaku Biro Hukum GMIH , tanggal 3/06/2020. 